ПРИЛОЗИ, Одделение за природно-математички и биотехнички науки, МАНУ, том 37, бр. 2, стр. 185-189 (2016)

CONTRIBUTIONS, Section of Natural, Mathematical and Biotechnical Sciences, MASA, Vol. 37, No. 2, pp. $185-189$ (2016)

Received: April 22, 2016

ISSN 1857-9027

Accepted: May 30, 2016

e-ISSN 1857-9949

UDC:597.551.2-144.1.086:[502.51:504.5(497.7)

DOI: 10.20903/CSNMBS_MASA.2016.37.2.43

Original scientific paper

\title{
MACROPHAGE AGREGATES IN BROOK BARBEL BARBUS CF. PELOPONNESIUS SPLEEN AS INDICATORS OF ENVIRONMENTAL POLUTION
}

\author{
Maja Jordanova $^{1 *}$, Marija Naskovska ${ }^{1}$, Vasil Kostov ${ }^{2}$, Katerina Rebok ${ }^{1}$ \\ ${ }^{1}$ Faculty of Natural Sciences, Ss. Cyril and Methodius University, Skopje, Republic of Macedonia \\ ${ }^{2}$ Institute of Animal Sciences, Skopje, Republic of Macedonia \\ "Corresponding author: majaj@pmf.ukim.mk
}

\begin{abstract}
Changes in fish macrophage aggregate centres (MACs) are a useful indicator of environmental stress. In this study we evaluated stereologically the values of these cells in the polluted sites compared to the clean site in the River Bregalnica. MACs aggregates were randomly distributed in spleen and often showed irregular form. Dominant pigment in them was hemosiderin. Relative volume of MACs aggregates showed significant higher value in brook barbel from polluted site. Total volume showed the same pattern, but differences were not significant. Our data confirm that increase in MACs aggregates may serve as to warn on potential pollution in aquatic ecosystems. However, the precaution is strongly suggested, as results were based on quantitative approach.
\end{abstract}

Key words: spleen; macrophage aggregates centres; pollution

\section{INTRODUCTION}

The environmental pollution presents a worldwide problem. According to some research in developed countries, $90 \%$ of waste waters are untreatedly discharged directly into the open water [1]. This problem is present in undeveloped counties as well. Persistence of toxic materials in aquatic ecosystems results in increased frequency of the infections, parasites and lesions in aquatic organisms, including fish [2-5]. This harmful effects are also manifested through negative influence of the toxic material upon MACs activity as well as on the whole immune system [6-8].

Pigmented MACs in fishes can be found in spleen, kidney and to a less extent in liver [9]. Number, size and pigment composition of MACs depend on various internal, i.e., endogenous factors [10-13]. Pigmented MACs also depend on the exogenous factors, namely on the presence of toxic materials in the environment [14, 16-18]. Most of the studies which investigated the influence of MACs on the environment in nature were qualitative [13].
Taking into account that MACs aggregates were good bioindicators for determination of the anthropogenous impact on environment and fish health [16], the present study aimed to investigate pigmented MACs aggregates in the brook barbell Barbus cf. peloponnesius spleen along the river of Bregalnica, both in a clean location, which was a reference site, and in the polluted ones. Stereologically (quantitatively) the amount of pigmented MACs, relative and total volume, in the selected organ was to be determined.

\section{MATERIAL AND METHODS}

Samples of brook barbel (Barbus peloponnesius, Valenciaennes, 1844) were collected from three locations in the River Bregalnica; the upstream, reference site ( $\mathrm{R}$ site), which does not receive anthropogenic effluents; the site in the middle part of the river (site A), which is under the strong pollution from aquaculture and mining industry; and the site in the downstream stretch (site B), which is mainly under sewage and household water 
discharges. The map and detail description of the sampling area were already published by Ivanova $e t$ al. [19]. In total, 648 fish samples were collected by electro fishing (electro fisher Samus 725G) from all three localities according to CEN EN 14011, 2003 standard. After the capture, the fishes were transported from sampling sites to the field laboratory. The animals were sacrificed by severing the spinal cord, the dissection was made and spleen was removed, measured for weight and fixed in Bouin's fixative for 48 hours. For analysis, the sampled pieces were routinely processed and embedded into paraffin. From each piece serial sections $(5 \mu \mathrm{m}$ thick) were taken, picking some of them for analysis by a systematic random sampling approach, so to obtain a representative final set of slides (about five per spleen). Sections were stained with Perl's method [20].

From each section, approximately ten systematically sampled fields were observed and quantified at a final magnification of $400 \times$, with the first field being randomly selected. In average, 50 fields per spleen were systematically selected and studied. A classical unbiased stereological technique based on manual point counting [21] was used to estimate the relative volume of the MACs (expressed as percentage) within the organ, according to the following formula:

$$
\begin{gathered}
\mathrm{VV}(\text { structure, reference })=\mathrm{VV}(\mathrm{s}, \mathrm{r}) \\
=[\mathrm{P}(\mathrm{s}) \times 100] \div \mathrm{P}(\mathrm{r}),
\end{gathered}
$$

in which $\mathrm{VV}(\mathrm{s}, \mathrm{r})$ is the percentage of the total volume of a reference space occupied by one particular given structure within that space, $\mathrm{P}(\mathrm{s})$ is the total number of test points lying over the reference space (in this study spleen tissue), and $\mathrm{P}(\mathrm{r})$ is the total number of points falling over a particular structural component. Point counting was directly made on a microscope, and for that a square lattice glass grid with 180 points was inserted into the left ocular. The total volume was calculated according to the following formula:

$$
\begin{aligned}
\mathrm{V}(\text { structure }) & =\mathrm{Vv}(\text { structure }, \text { reference }) \\
& \times \mathrm{V}(\text { reference })
\end{aligned}
$$

Data were presented as group means of individual fish values, accompanied with the Coefficient of Variation $(\mathrm{CV}=\mathrm{SD} /$ mean). Statistical analyses were made using the software Statistica 7.0 for Windows. Data were analyzed by ANOVA and whenever ANOVA disclosed significant results the post-hoc Tukey test was performed. Differences were considered as significant at $p<0.05$.

\section{RESULTS AND DISCUSSION}

Pigmented MACs aggregates were randomly distributed through the spleen tissue in examined brook barbel (Figure 1). The main pigment inside them was hemosiderin alone (Figure 1b), or sometimes in association with lipofuscin/ceroid. The melanin was almost absent. Such a distribution of the pigment in brook barbel spleen was in accordance with the data of the other authors [9-11]. Moreover, the hemosiderin deposition in MACs indicated to the presence of toxic materials in environment [16].

As expected from the qualitative analyses, the highest VV(MACs, spleen) were observed in fish sampled at the sites A and B (Tab. 1). These values were significantly higher when compared with the fish taken from the $\mathrm{R}$ site. Total volume $\mathrm{V}_{\text {spleen }}$ (MACs) showed tendency to increase in polluted sites, but no significant differences were obtained, probably due to high coefficient of variation coming from strong individual variability (Tab.1).

In fishes, MACs have a function in organism defense. Numerous data show that pollution in the environment influences MACs [15-17]. It is in agreement with our data, which confirmed that MACs are good bioindicators for early detection of presence of the toxic materials in aquatic ecosystem. Fournie et al. [18] already pointed that MACs can easily reveal the difference between degraded and non-degraded environments. Most of the studies in which MACs were used as potential biomarker were based on qualitative observation. When studies were quantitative, different researchers measured different parameters and hence, a consistent conclusion about their utility is lacking. Therefore, we strongly suggest a quantitative approach in the use of MACs as a bioindicator. 

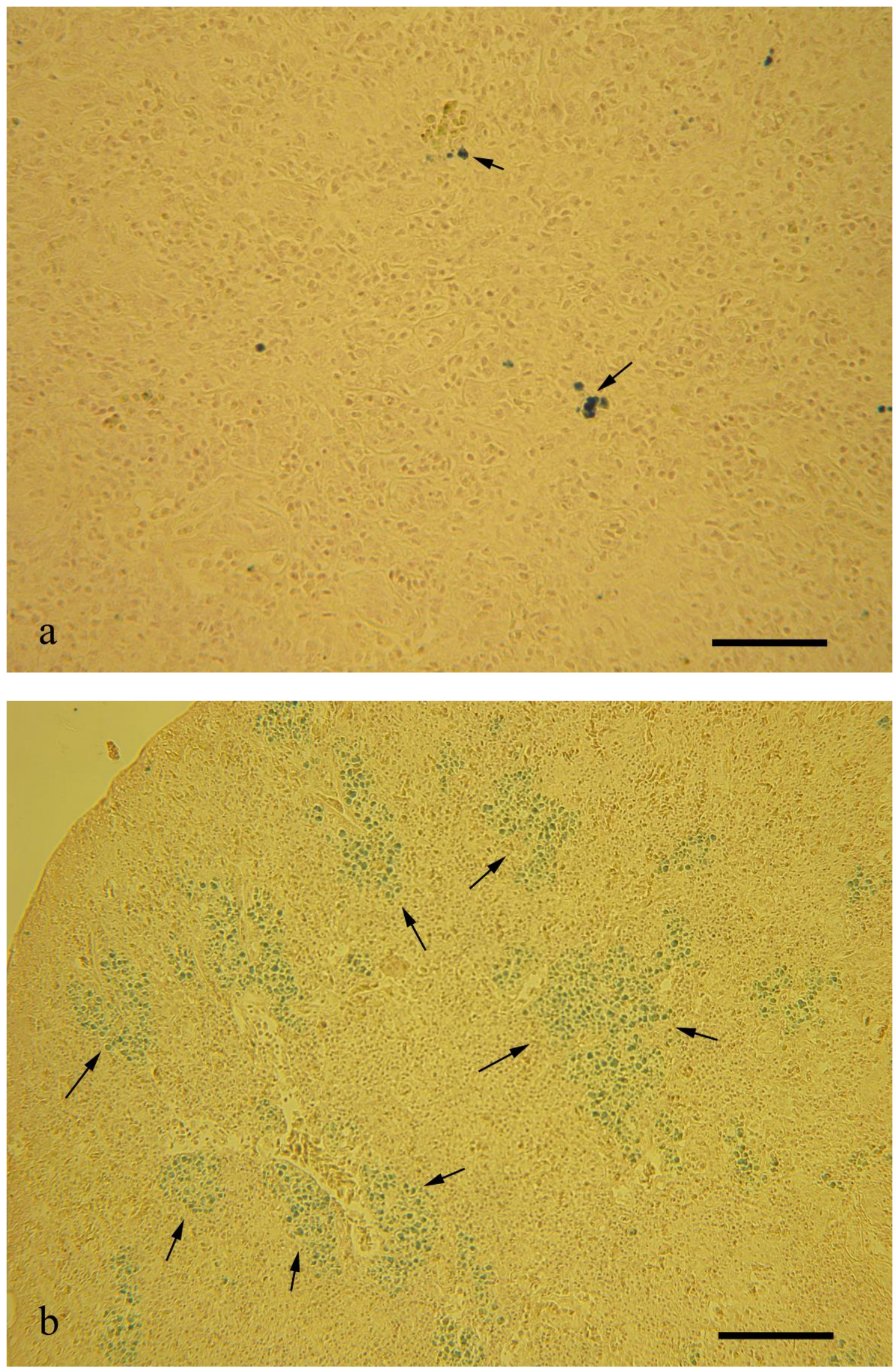

Figure 1. Light micrographs of Perl's stained sections from the spleen of barbel, showing the evident difference between (a) fish in the reference site with fewer pigmented macrophage aggregates (MACss), and (b) fish in the polluted location with much extensive accumulations pigmented MACs amidst. Bar line $=100 \mu \mathrm{m}$. 
Table 1. Relative volume $\left(\mathrm{V}_{\mathrm{V}}\right)$, and total volume $(\mathrm{V})$ of the pigmented macrophage aggregates (MACs) in the spleen of the barbel from reference site (R site), and sampling sites affected with pollution effluent ( $\mathrm{A}$ and $\mathrm{B}$ sites)

\begin{tabular}{lcc}
\hline \multirow{2}{*}{ Location } & $V_{\mathrm{V}}($ MACs, spleen kidney) & $\begin{array}{c}\mathrm{V}_{\text {spleen }}(\mathrm{MACs}) \\
\mathrm{cm}^{3}\end{array}$ \\
\hline R Site & $0.93(1.65)^{\mathrm{a}}$ & $0.02(2.61)$ \\
A Site & $2.06(0.01)^{\mathrm{b}}$ & $0.04(1.55)$ \\
B Site & $1.50(1.02)^{\mathrm{b}}$ & $0.05(2.82)$ \\
\hline
\end{tabular}

Data are expressed as: mean (coefficient of variation).

Within a column, values with different superscript letters are significantly different $(p<0.05)$, according to the post-hoc Tukey's test.

\section{REFERENCES}

[1] UNEP International Environment. Environmentally Sound Technology for Wastewater and Stormwater Management: An International Source Book. IWA Publishing. 2002, ISBN 1-84339-008-6. OCLC 49204666.

[2] R. A. Murchelano, Fin erosion in winter flounder. Mar. Pollut. Bull., 6 (1975), pp. 26-29.

[3] R. M. Overstreet, H. D. Howse, Some parasites and disease of estuarine fishes in polluted habitats of Mississippi. Ann. N.Y. Acad. Sci., 298 (1977), pp. 427-462.

[4] D. E. Hinton, R.C Lantz, J. A .Hampton, P. R. McCuskey, R. S. Cuskey, Normal Versus Abnormal Structure: Considerations in Morphologic Responses of Teleosts to Pollutants. Environ. Health Perspect. 71 (1987), pp. 139-146.

[5] A. K. Whitfield, M. Elliott, Fishes as indicators of environmental and ecological changes within estuaries: a review of progress and some suggestions for the future. J. Fish Biol., 61 (2002), pp. 229-250.

[6] T. Meinelt, R. Kriiger, M. Pietrock, R. Osten, C. Steinberg, Mercury pollution and macrophage centers in pike (Esox lucius) tissues. Environ. Sci. Pollut. Res. 4(1) (1997), pp. 32-36.

[7] M. Manera, R. Serra, G. Isani, E. Carpené, Macrophage aggregates in gilthead sea bream fed copper, iron and zinc enriched diets. J. Fish Biol. 57 (2000), pp. 457-465.

[8] J. E. Hinck, V. S. Blazer, N. D. Denslow, M. S. Myers, T. S. Gross, D. E. Tillitt, Biomarkers of Contaminant Exposure in Northern Pike (Esox lucius) from the Yukon River Basin, Alaska. Arch. Environ. Contam. Toxicol., 52 (2007), pp.549-562.

[9] C. Agius, R. J. Roberts, Melano-macrophage centers and their role in fish pathology. J. Fish Dis., 26 (2003), pp. 499-509.

[10] V. S. Blazer, R. E. Wolke, J. Brown, C. A. Powell, Piscine macrophage aggregate parameters as health monitors: effect of age, sex, relative weight, season and site quality in largemouth bass (Micropterus salmoides). Aquat. Toxicol., 10 (1987) 199-215.
[11] A. R. Schwindt, N. Truelove, C. B. Schreck, J. W. Fournie, D. H. Landers, M. L. Kent, Quantitative evaluation of macrophage aggregates in brook trout Salvelinus fontinalis and rainbow trout $\mathrm{On}$ corhynchus mykiss. Dis. Aquat. Org., 68 (2006), pp. 101-113.

[12] M. Jordanova, N. Miteva, E. Rocha, A quantitative and qualitative study of the hepatic pigmented macrophage aggregates during the breeding cycle of Ohrid trout, Salmo letnica Kar. (Teloestei, Salmonidae). Micros. Res. Tech., 71 (2008), pp. 822-830.

[13] M. Jordanova, M. J. Rocha, K. Rebok, E. Rocha, Changes in the amount of kidney pigmented macrophage aggregates throughout the breeding cycle of female Ohrid trout, Salmo letnica Kar. (Teloestei, Salmonidae). Micros. Res. Tech., 75 (2) (2011), pp.176-181.

[14] R. E. Wolke, Piscine macrophage aggregates: a review. Annu. Rev. Fish. Dis., 2 (1992), pp. 91-108.

[15] J. W. Fournie, J. K. Summers, L. A. Courtiney, V. D. Engle, Utility of splenic macrophage aggregates as an indicator of fish exposure to degraded environments. J. Aquat. Anim. Health., 13 (2001), pp. 105-116.

[16] V. S. Blazer, W. K. Fournie, B. A. Weeds, Macrophage aggregates: biomarker for the immune functions of fishes, in Environmental Toxicology and Risk Assessment, 6: Modeling and Risk Assessment, F. G. Dwyer, T. T. Doane, M. L. Hinmman, P. A. Conshohocken (Eds.) American Society for Testing and Materials, 1997, pp. 360-375.

[18] D. E. Facey, V. S. Blazer, M. M. Gasper, C. L. Turcotte, Using Fish Biomarkers to Monitor Improvements in Environmental Quality. J. Aqua. Anim. Health, 17 (2005), pp. 263-266.

[19] J. W. Fournie, J. K. Summers, L. A. Courtiney, V. D. Engle, Utility of splenic macrophage aggregates as an indicator of fish exposure to degraded environments. J. Aquat. Anim. Health, 13 (2001), pp. 105-116.

[20] L. Ivanova, F. Popovska-Percinic, V. SlavevskaStamenkovic, M. Jordanova, K. Rebok, Micronuclei and nuclear abnormalities in erythrocytes from barbel (Barbus peloponnesius) revealed genotoxic pollution of the river Bregalnica. Mac. Vet. Rev. 39 (2) (2016), pp.159-166. 
[21] M Perls, Prussian blue staining protocol. Arch. Pathol. 39 (1867), pp. 42-42.
[22] H. Freere, E. R. Weibel, Stereologic techniques in microscopy. J. R. Microsc. Soc., 87 (1967), pp. $25-34$.

\title{
МАКРОФАГНИ АГРЕГАТНИ ЦЕНТРИ ВО СЛЕЗИНАТА НА МРЕНАТА ВАRВUS CF. PELOPONNESIUS КАКО ИНДИКАТОРИ НА ЗАГАДУВАЫЕТО НА СРЕДИНАТА
}

\author{
Маја Јорданова ${ }^{1}$, Марија Насковска ${ }^{1}$, Васил Костов ${ }^{2}$, Катерина Ребок $^{1}$ \\ ${ }^{1}$ Природно-математички факултет, Универзитет „Св Кирил и Методиј“, \\ Скопје, Република Македонија \\ ${ }^{2}$ Институт за сточарство, Скопје, Република Македонија
}

\begin{abstract}
Промените во макрофагните агрегатни центри (MACs) кај рибите се корисен индикатор за стресна состојба во животната средина. Во оваа студија со стереолошки методи направивме процена на овие клетки во загадени наспрема незагадени локалитети во реката Брегалница. MACs агрегати се расфрлени низ слезината и се често со неправилна форма. Доминантен пигмент во нив беше хемосидеринот. Релативниот волумен на агрегатите на MACs покажа статистички значително повисоки вредности во загадените локалитети. Тоталниот волумен покажа ист тренд, но разликите не беа статистички значајни. Нашите резултати потврдуваат дека зголемувањето на MACs-агрегати може да се користи како предупредување за потенцијално загадување на акватичните екосистеми. Затоа, сугерираме резултатите од ваквите истражувања да бидат од квантитативна природа.
\end{abstract}

Клучни зборови: слезина; макрофагни агрегатни центри; загадување 
